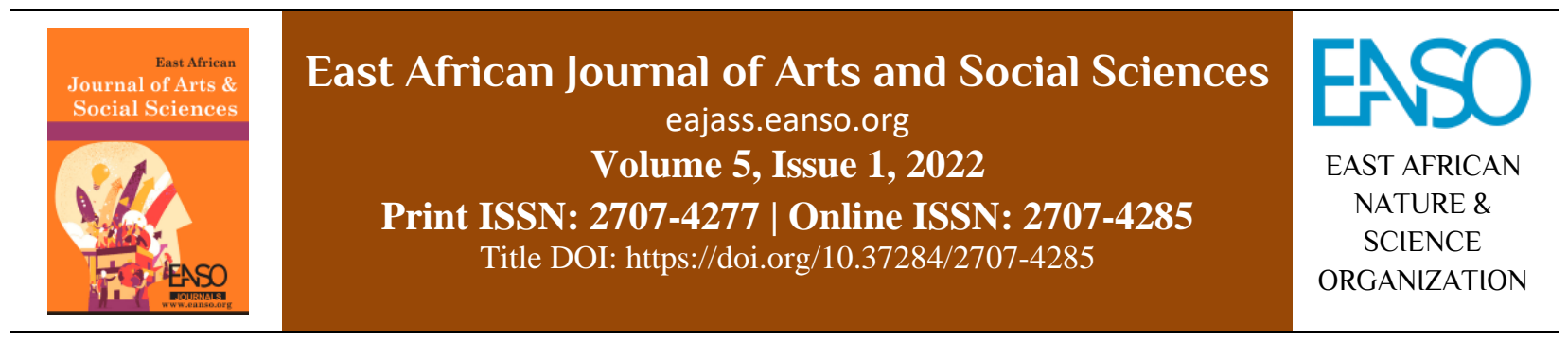

Original Article

\title{
Re-examining Notions of Transnationalism, Cosmopolitanism and Xenophobia in Postcolonial Africa: A Textual Analysis of Teju Cole's Open City
}

\author{
Kipkoech Mark Chepkwony ${ }^{*}$, Prof. Nicholas Kamau, $P h D^{1} \&$ Dr. Stephen Mutie, PhD ${ }^{2}$ \\ ${ }^{1}$ Laikipia University P. O. Box 1100 - 20300. Nyahururu, Kenya. \\ ${ }^{2}$ Kenyatta University P. O. Box 43844 - 00100 Nairobi, Kenya. \\ *Correspondance email : mark.kipkoech8@gmail.com.
}

Article DOI: https://doi.org/10.37284/eajass.5.1.570

\section{Date Published: ABSTRACT}

08 March 2022 This article looks at how ideas of transnationalism, cosmopolitanism and xenophobia are dramatized in the postcolonial novel in the Teju Cole's Open City.

Keywords: The article examined transnationalism and cosmopolitanism as the quest that

Transnationalism, compels characters in the novel to move out of their initial localities; interrogated

Cosmopolitanism, how the selected novel attempts to re-read the transitional mode of subjectification

Xenophobia, Afropolitanism. occasioned by transnationalism, cosmopolitanism and xenophobic attacks on immigrants and established why the immigrants in the text face the xenophobic treatment and how they negotiate the cross-cultural complexities of their new worlds. This article leaned on Taiye Selasi's Afropolitanism theory. The article used close reading of Open City, exploring themes and motifs in the text. Data was analysed using content and thematic analysis. The article found out that the notions of transnationalism, cosmopolitanism and xenophobia in postcolonial Africa have birthed new identities which have been engaged and interrogated by the Teju Cole in Open City. The paper concluded that the notion of Afropolitanism, with its focus on both rootedness and movement, must be understood as an effort to bring together two divergent frameworks for an understanding of African identity. This article will benefit scholars in the field of migrations, human rights, and globalisations by tackling and exposing the complex view of globalisation, a criticism that transcends national boundaries, colonial worldviews, and postcolonial geopolitics and is based on mutual informing assumptions. It benefits literary studies, especially identity studies and African studies, because it interrogates how migrations bring out new identities and how these new identities stretch the understanding of the new direction of African literature.

13 This work is licensed under a Creative Commons Attribution 4.0 International License. 


\section{APA CITATION}

Chepkwony, K. M., Kamau, N \& Mutie, S. (2022). Re-examining Notions of Transnationalism, Cosmopolitanism and Xenophobia in Postcolonial Africa: A Textual Analysis of Teju Cole's Open City. East African Journal of Arts and Social Sciences, 5(1),13-22. https://doi.org/10.37284/eajass.5.1.570

\section{CHICAGO CITATION}

Chepkwony, Kipkoech Mark., Nicholas Kamau \& Stephen Mutie. 2022. "Re-examining Notions of Transnationalism, Cosmopolitanism and Xenophobia in Postcolonial Africa: A Textual Analysis of Teju Cole's Open City". East African Journal of Arts and Social Sciences 5 (1), 13-22. https://doi.org/10.37284/eajass.5.1.570.

\section{HARVARD CITATION}

Chepkwony, K. M., Kamau, N. \& Mutie, S. (2022) "Re-examining Notions of Transnationalism, Cosmopolitanism and Xenophobia in Postcolonial Africa: A Textual Analysis of Teju Cole's Open City", East African Journal of Arts and Social Sciences, 5(1), pp. 13-22. doi: 10.37284/eajass.5.1.570.

\section{IEEE CITATION}

K. M. Chepkwony, N. Kamau, \& S. Mutie. "Re-examining Notions of Transnationalism, Cosmopolitanism and Xenophobia in Postcolonial Africa: A Textual Analysis of Teju Cole's Open City”, EAJASS, vol. 5, no. 1, pp. 13-22, Mar. 2022.

\section{MLA CITATION}

Chepkwony, Kipkoech Mark., Nicholas Kamau \& Stephen Mutie. "Re-examining Notions of Transnationalism, Cosmopolitanism and Xenophobia in Postcolonial Africa: A Textual Analysis of Teju Cole's Open City". East African Journal of Arts and Social Sciences, Vol. 5, no. 1, Mar. 2022, pp. 13-22, doi:10.37284/eajass.5.1.570.

\section{INTRODUCTION}

Whether forced or deliberate, migration over occasions new identities produced within the contexts of Transnationalism, cosmopolitanism, and diasporic experiences. These new transnational and cosmopolitan identities have blurred the ideas of home and away and have birthed a new quest for belonging, bringing forth xenophobic attacks that have been a persistent theme in the postcolonial novel, especially the post-2000 literature (Mbembe, 2007; Bhabha, 1994). There has been a steady increase in studies on cosmopolitanism in literature during the last two decades. It is directly tied with interconnection and encounters with a difference on an unparalleled size as a result of cross-border commerce, migration, mobility, media, and consumption taking place on an unprecedented scale. In this view, individualisation is presupposed by transnationalism and cosmopolitanism.

On the other hand, a cosmopolitan identity is an expression of selfhood that transcends cultural identifiers and social connections. However, these studies have not interrogated how the interplay of cosmopolitanism, Transnationalism and the hurt and harm occasioned by some diasporic experiences like xenophobic attacks bring forth new identities. This article examined the diasporic experiences that give rise to these identities - using transnationalism and cosmopolitanism as cultural resources, this article aimed at doing this by challenging sociocultural and political dynamics occasioning migration(s) and dislocations to countries and the lures and assumptions occasioned by the idea of diaspora.

\section{Teju Cole's Julius in Open City}

The issue of identity development is explored in further depth in this section as discussed by Selasi (2005). The theorist argues that the Afropolitan is riddled with a series of traits forged at the personal and national levels. In Open City, Teju Cole constructs characters with "semi-biographies", which helps locate how their migration stories initiate their search for identity.

This section examines the following characters' exemplification of their identity formation; Julius, Professor Saito, and Saidu. Thus, by examining the individualized journeys of characters', we uncover how their identity is shaped. The Afropolitan uniqueness imbues a hybrid of cultures whose combination nods to the globalized accolade. Selasi uses her personal experience as the yardstick of defining the Afropolitan,

They (read: we) are Afropolitans. [...] there is at least one place on the African continent to which we tie our sense of self: be it a nation-state (Ethiopia), a city (Ibadan), or an auntie's

14 | This work is licensed under a Creative Commons Attribution 4.0 International License. 
kitchen. Then there's the G8 city or two (or three) that we know like the backs of our hands and the various institutions that know us for our famed focus. We are Afropolitans: not citizens, but Africans of the world. (https://blog.politics.ox.ac.uk/afropolitanismglobal-citizenship-with-african-routes)

In effect to the above description, Teju Cole in Open City crafts characters that display the models of the Afropolitan. Identity is the key marker of this unique group of Africans whose existence is not bound by physical borders. While quoting Mbembe (2007), Ucham (2013) retaliates that,

Afropolitanism is an aesthetic and a particular poetic of the world. It is a way of being in the world, refusing on principle any form of victim identity - which does not mean that it is not aware of the injustice and violence inflicted on the continent and its people by the law of the world. It is also a political and cultural stance in relation to the nation, to race, and to the issue of difference in general (p. 28-29).

The above definitions of the Afropolitan correspond to the Open city imaginative display of characters.

For instance, Julius, the main protagonist, emerges from the ruins of a botched relationship with his girlfriend Nadege and tries to heal his dented self. In his thirties, Julius is a psychiatric fellow in the university at the Columbia-Presbyterian Hospital and is inundated with the burning desire to fix his split identity crisis that stems from his biracial origin. Forced to migrate out of Nigeria in his youth, he migrates to America to pursue better life opportunities. After arriving on the US shores, he navigates through university and makes friends with different people who, just like him, have endured a troubled past. To circumspect his troubled personal life, Julius resorts to diagnosing the people around him in an attempt to vindicate his fragmented life. His candid interactions revolve around the intricate matters of personal bonds, shattered nationalities, and nostalgic memories.

Having escaped from Nigeria with scars of dark life, Julius' past doings seem to follow him everywhere. In New York, Julius open walks paint to a searching soul that tries to locate its lost social compass by connecting with random people he meets on the streets. Julius mixed racial background is always symbolic of the "ground zero" moment that shatters his personality. While wandering in the streets of New York, his life cuts a lonely man who tries to seek refuge in an open world away from a failed past.

Although we are introduced to Julius when he is middle-aged, his genesis is traced in Nigeria, where a family feud split him with his mother at seventeen. Julius laments that the broken bond with his maternal mother created a rift that would lead him to eventually migrate to America. His multiracial heritage makes it difficult to repair the damaged relations with his mother. Julius notes,

I tend to connect this to my mother's estrangement from her own mother. They might have fallen out for reasons as inchoate as that separated my mother and me. My mother had not returned to Germany since she left in the 1970s. Nevertheless, in recent years I have thought of my oma more often (p. 34).

Julius split personality makes it difficult to get along with his family, which renders him to live in solitude. The racial difference in his maternal lineage plays out in the most despicable way. Julius' mother cuts out communication with his grandmother, a development that makes Julius get into an emotional detachment with his mother. To circumnavigate this development, Julius opts to undertake the arduous task of globetrotting to repair broken family ties.

Race plays a huge in Julius' identity formation; as a free man in the west, his mission is to amend his troubled selfhood that is permeated with puzzles of missed affection. As an immigrant, his life in the US, Julius is constantly affected by the identity crisis that he tries to solve. Julius tries to heal and rediscover himself in the global space through mental and physical dislocation. The racial dilemma affects his social life, and at times, it pricks his identity, causing Julius to rethink of his African heritage. This is showcased when he narrates on a dinner he had with an Indian- American family,

Dr. Gupta ushered us into one of his three lavish rooms and went round pouring champagne into our glasses. He and his family, he told us, had been expelled from their homes and lands by Idi 
Amin. I am successful now, he said; America has made a life possible for my wife and children and for me. My daughter is doing graduate studies in engineering at MIT, and our youngest is at Yale. But, if I may speak frankly, I'm still angry. We lost so much, we were robbed at knifepoint, and when I think about Africans- and I know we are not supposed to say such things in Americawhen I think about Africans, I want to spit (p. 30).

In this scene, Julius is angered by vile comparison to the ruthless dictator Idi Amin and this nasty moment awakens the stereotype associated with black people. As the only African in the room, referring to Amin's brutalization and forceful eviction of Asians living in Uganda, the xenophobic memories are rekindled on American soil. With this experience, Julius feels that his identity is targeted primarily due to his skin colour by his IndianAmerican host. To resolve the identity quagmire, Julius resorts to invoking his global worldview to settle the divergent views emanating from the topical issue of racial identity. For instance, after being racially profiled by Dr. Gupta, Julius deeply reflects on the actual documentation of the horrific Ugandan history when Amin was in power.

To deal with the shame of being labelled as an "ugly" African, Julius details a brief historical backdrop of the whole incident in Uganda as a strategy that helps usurp the construed image of Africa. He argues that the prevalent imagery documented in the west misses the whole story about the African people. Therefore, Julius tries to salvage the demonized image of Africa, which tries to rise from the ashes of a failed system. This is evident when he posits,

I saw that Idi Amin himself hosted wonderful parties, told genuinely funny jokes, and spoke eloquently about the need for African selfdetermination. These nuances in his personality, as depicted here, would no doubt have brought a bad taste to the mouth of my host in Madison ( $\mathrm{p}$. 41).

In the above quote, Julius tries to wrestle with the account of Amin's relations with the people he oppressed. By revisiting the awkward experience, Julius' mutative identity provides no solution to his narrative prowess that documents the psychological torture he endures from racially motivated jibe from his host. He likens Amin's atrocious treatment of his people as an act of revenge by his host on Black people. Julius also feels he is a target of racial inequality in America, a development that sees him become a victim of white prejudice. This is seen when coming out of a movie he is ridiculed by young children who within the vicinity of their parents wrongly accuse Julius as a dangerous person probably associated with a gang,

They now both turned to me. Are you a gangster, mister? They both flashed gang signs, or their idea of gang signs. I looked at them. It was midnight, and I didn't feel like giving public lectures. He is black, said the girl, but he's not dressed like a gangster. I bet he's a gangster, her brother said (p. 32).

Julius's battle with self-identification means he cannot fit in the open space that he hoped to seek refuge. Unable to align himself to a specific ethnic grouping, he finds himself bumping into people with different social-cultural backgrounds. At times, he is on the receiving end of their hostilities. The two incidents of Dr. Gupta and the two young children who chide people of colour give a gist of how Julius's identity as a black man in the US affects his sense of belonging. The racial jibes directed to him collapse his effort to mend his ruptured identity.

\section{(Un)Open Spaces for the Black Migrant in Western Urban Centres in Cole's Open City}

\begin{abstract}
Dr Gupta ushered us into one of his three lavish living rooms and went round pouring champagne into our glasses. He and his family, he told us, had been expelled from their homes and lands by Idi Amin. I am successful now, he said. America has made life possible for me and my wife and children.... but if I may speak frankly, I'm still angry. We lost so much, we were robbed at knifepoint, and when I think about Africans - and I know we are not supposed to say such things in America- when I think about Africans, I want to spit...the bitterness was startling. It was an anger that I couldn't help feeling, was partly directed at me, the only other African in the room. The detail of my background that I was Nigerian made no difference, for Dr. Gupta had spoken of Africans,
\end{abstract}

16 | This work is licensed under a Creative Commons Attribution 4.0 International License. 
had sidestepped the specific and expressed in the general [...] They both turned to me. Are you a gangster, mister? Are you a gangster? He's black, said the girl, but he's not dressed like a gangster. I bet he's a gangster, her brother said, $I$ bet he is. Hey mister, are you a gangster? (Cole, p. 30-32).

As can be deciphered from the epigraph introducing this section, one resounding topic in Open City is the complexities of racial identification, particularly for those belonging to the race often referred to as black. Cole investigates how African migrant identity challenges the monolithic categorization of black

Identity in western cities, particularly in the United States. In Open City, Cole walks the reader through the process of seeing race as a tangled web, particularly in metropolitan areas. By include Julius and other black people in the story, Cole draws the reader's attention to the disjunction between different ethnicities' colour and identity in an urban setting. Open City, in particular, calls attention to the complicated identity that blackness symbolizes in an age defined by voluntary global travel and migrant workers. More importantly, the narrative sheds light on the general perception of black identity in western cities and how this complicates the process of negotiating one's place in society for the African migrant.

For example, Julius, the narrator, and critical character of the narrative, feels himself to be a global citizen and is captivated by the cultures and histories of many races. While his skin tone classifies him as black (as in African American) in New York, he is constantly met with a critical stare from both white New Yorkers and African Americans on every corner he turns, regardless of his ethnicity. On the other hand, Julius has no African American sensibility and refuses to be labelled as one in real life. Instead, he describes himself as a multiracial migrant with roots in various cultures, geographies, and identities, all of which he has accumulated through time. On the other hand, the metropolis is entirely unaware of Julius's complicated status as a coloured migrant. Therefore, he finds it challenging to identify with the city and prefers to watch it as an explorer rather than a native New Yorker, allowing him to understand better the people and places he encounters.

Furthermore, via the multifaceted character of the narrator, Cole illustrates how African migrants are rendered invisible in the racial configuration of western cities, as their identity is swallowed into the coloured end of the default racial division in western society. Julius' experience with two young white adolescents at the theatre, who, upon seeing him, immediately refer to him as "African American," demonstrates the degree to which individuals are classified from a racial binary viewpoint. Julius describes his meeting with the adolescent in the following way:

Hey mister, she said, turning to me, wassup? She made signs with her fingers and, with her brother, started laughing. ...Are you a gangster, mister? Are you a gangster? They both flashed gang signs, or their idea of gang signs. I looked at them. It was midnight, and I didn't feel like giving public lectures. I bet he's a gangster, her brother said, I bet he is. Hey mister, are you a gangster? They continued flicking their fingers at me for several reasons (p. 31-32).

One resounding topic in Open City is the complexities of racial identification, particularly for those belonging to the race often referred to as black. Cole investigates how African migrant identity challenges the monolithic categorization of black identity in western cities, particularly in the United States. In Open City, Cole walks the reader through the process of seeing race as a tangled web, particularly in metropolitan areas. By include Julius and other black people in the story, Cole draws the reader's attention to the disjunction between different ethnicities' colour and identity in an urban setting. Open City, in particular, calls attention to the complicated identity that blackness symbolizes in an age defined by voluntary global travel and migrant workers. More importantly, the narrative sheds light on the general perception of black identity in western cities and how this complicates the process of negotiating one's place in society for the African migrant.

Throughout, Cole conveys the Afropolitan desire for the world to comprehend blackness from a variety of perspectives and to respect the distinctive character of African migrants. Also highlighted are 
the difficulties that African migrants face continuously in a globalized society that is disadvantaged and has a bad image of the black race to contend with. When questioned in the same interview if he has ever had any "anguish" while on his intellectual journey across the globe, he responds emphatically with the phrase "travelling while black!" This is the spirit that permeates Open City. I do not mean, however, to imply that Teju writes himself as Julius in the story due to this reasoning. The fact that Teju's politics can be heard in Open City, on the other hand, may be unassailable. As Julius makes his way from Nigeria to New York, through New York, and finally to Brussels, he is constantly reminded of his differences and the negative connotations that the cities have attached to his skin colour because of his ethnicity.

The experiences and worries of African immigrant characters in Open City have considerable parallels to those of diasporic African authors who have described their own experiences and fears, even as transnational intellectuals when seen in a critical light. The disappointment caused by the city's rejection toward their intended membership continues to be felt by this group, despite their willingness to embrace western civilizations in which they have a stake primarily because of their colonial background.

Initially, Julius's experiences are projected as a manifestation of this sensitivity. Even though he is well aware of the racial inequalities in New York, he exhibits a feeling of difference that allows him to feel immune from such barriers. That he feels like a free man in an "open city" is not unrelated to his unique past as a well-educated guy with a valid twofold claim to European heritage: a German mother and a Nigerian father, to name a few factors. Moreover, Julius is both European and Nigerian by his multiracial origin, indicating even another layer of hybridity in his postcolonial subjectivity as a result of this. As a result of his upbringing, he feels distinct from other African-Americans in New York. After a while, he realizes that society does not consider him any different from other persons of colour, and the narrative continues. On another level, Julius appreciates working with a welleducated, well-cultured psychiatrist who does an excellent job in a well-respected profession. The story's sequence of interactions, on the other hand, demonstrates that his apparent socioeconomic rank does not insulate him from being subjected to prejudice. The previously mentioned encounter with the children, Mr Gupta, and of course Dr Maillotte, the Belgian lady who believes that "many Nigerians are arrogant" and that Ghanaians are better to work with "because they do not have such a large concept of their place in the world" are all examples of this (88)

A second way Open City complicates the subject of race in western cities in light of the experiences of African migrants is via Julius' encounter with Farouq and his fellow refugees in Brussels. The reader's attention is brought to the untruth implicit in Julius' recounting of his Brussels experience from the minute he arrives in the city in the novel's first paragraph. Julius' landlady, Mayken, who had volunteered to pick him up from the airport for a price, tells him about the ethnic makeup of the city as they travel from the Brussels airport to his leased temporary flat. Julius' landlady, Mayken, had offered to pick him up from the airport for a fee. There is a lot of unhappiness in Mayen's knowledge about the existence of various ethnic nations in the city other than her Flemish ethnicity, which is reflected in her writing. Even though the Dutchspeaking Flemish comprise the ethnic majority in Brussels, Mayken would like a city that is 100 per cent Flemish, as she expresses her regret:

The original idea of Brussels was that it should be equally Flemish and Walloon. Of course, it's not that way anymore...now, it is ninety-five percent Walloon and other French speakers, one percent Flemish, and four present Arab and African (Cole, p. 96).

Interestingly, Mayken's statement here alludes to a notion held by the ordinary Flemish in Brussels, who, when given the opportunity, is quick to show irritation at the presence of persons of various ethnic backgrounds. The dismissive attitude toward the African company in the city, as Julius' narrative would later demonstrate, epitomizes the anonymity with which African and Arab migrants are perceived in European cities. Accordingly, Julius makes the following correction:

I'm sure Mayken's "Arab and African" was intended to be snide. Even in the city center, or 
especially there, many people seem to be from some part of Africa, either from the Congo or from the Maghreb. As I was to discover, whites were a tiny minority on some trams quickly (Cole, p. 98).

Julius' comment, which has been reproduced here, does not imply that Brussels is a city with most immigrants. But it dispels the myth that Africans and Arabs make up a small proportion of the immigrant population in European cities, as some have claimed. Because it is difficult to go through the city centre without recognizing African immigrants, Julius points out how white Brussels can quickly consign such individuals to invisibility. Mayken's assessment of non-Flemish residents in Brussels as unimportant is consistent with how the city views and handles these immigrants, regardless of their number or visibility.

In the aftermath, Open City draws attention to the discrepancy between the identities that African and Arab migrants get in Europe's "open cities" and the identities that these immigrants describe as being genuine to themselves. Cole emphasizes this point via Julius' account of a sequence of occurrences that raise concerns about Brussels' openness to persons of ethnic backgrounds other than those of Belgian ancestry. One such incidence occurred in Brussels, when a seventeen-year-old was stabbed and bled to death in the presence of hundreds of witnesses, none of whom came to his rescue.

Immediately after the youngster's death, the city's bishop, in his sermon, blames the killing not only on the killer but also on the others who stood by and did nothing while a fellow person was fighting for his life. However, opinion moulders in the city believe that the people themselves are victims and should not be blamed for doing anything while a crime occurs in their full glare. This is what Julius says in his narration:

Well-known columnists took a wounded tone and complained of reverse racism. The victims were being blamed, they said. The problem was not with uncaring passersby but with the foreigners who committed crimes. One journalist wrote that Belgian society was fed up with "murdering, thieving, raping Vikings from North Africa". This was quoted approvingly in specific mainstream sources. ...But the murderers, it turned out, weren't Arab or African at all: They were Polish citizens. One of them was arrested in Poland; his partner was arrested in Belgium and deported to Poland (Cole, p. 99).

Tragically, this kind of scenario accurately depicts the reality of how migrants from certain nations and of various colours are seen in western cities, especially in the current context of much-touted globalization, according to the author. The insulting hate vocabulary used by specific significant media channels and the right-wing opinion and political leaders to demonize African and Arab migrants, framing them as economic stresses and security risks to the host people, is widespread. As a result, not only is the safety of such immigrants jeopardized, but it also has a psychological impact on their ability to call their new nation of residency home in the future. While this is happening, they are continually reminded that they do not belong in this city, whose customs and traditions they have been submerged in.

Julius goes on to describe a series of instances involving anti-black immigration that occurred in many Belgian towns during his brief stay in Brussels, including the following:

I was there at the very end of 2006, a year in which several hate crimes had ratcheted up the tension experienced by non-whites living in the country. In Bruges, five skinheads put a black Frenchman into a coma. In Antwerp, in May, an eighteen-year-old headed for the city centre with a Winchester rifle and started shooting. He seriously injured a Turkish girl and killed a nanny from Mali and the Flemish infant in her care. Later on, he expressed a specific regret: accidentally shot the white child. In Brussels, a black man was left paralyzed and blind after an attack at a petrol station. The paradoxical results of these crimes was that even the centrist parties began to lean rightward to cater to voter discontent about immigration (Cole, p. 99-100)

To emphasize how accurate these fabricated occurrences are to the reality of the current 'globalized world,' I have referenced it extensively to demonstrate how one race of people can benefit from actual globalization while others are denied the benefits of true globalization. Example: In January 2018, President Donald Trump was widely

19 | This work is licensed under a Creative Commons Attribution 4.0 International License. 
quoted as saying that it would be preferable for the United States to accept immigrants from nations such as Norway rather than Haiti and "shithole" countries in Africa. However, there have been times in which the same president has referred to Mexicans as rapists and drug dealers while simultaneously referring to Muslims as terrorists. This has resulted in pockets of hate crime against immigrants, similar to those described in Open City, who have been targeted against.

Cole demonstrates that anti-immigrant rhetoric in western countries and cities, as well as the resulting brutal assaults on immigrants that they generate, invariably result in a dimming of the cosmopolitan expectations and disposition of the African migrants to the world, causing them to withdraw into the shells of national and regional sentiment. Although Julius lived alone in New York, he kept his global outlook on life, despite the discriminatory treatment he received in a few isolated pockets of New York City. On the other hand, his journey to Brussels brings him face to face with the limits of cosmopolitanism. Julius learns the lack of suitable cosmopolitan ideals in western cities after seeing a series of heinous but premeditated assaults against immigrants in various Belgian towns and cities. More importantly, his contact with Farouq, a Moroccan store owner and internet café proprietor in Brussels, aids him in processing and making sense of his New York existence, which he sees as no different from the lives of every other black guy in both the United States and Belgium. Following a lengthy chat with Farouq, Julius confronts his own identity as an African immigrant. During his speech, he reflects on the vast disparity between the way African immigrants are seen by their white hosts and their genuine identities as African immigrants. Even though Farouq will always be simply "a guy in the store" to the white host, who may never be prepared to engage him in any meaningful discourse, he impresses Julius as a scholar with the ability to have a beneficial impact on the city, which is warmly welcomed by Julius.

Julius believes the following:

Here he was, as anonymous as Marx in London. To Mayken and countless others like her in the city, he would be just another Arab, subject to a quick, suspicious glance at the tram (Cole, $\mathrm{p}$. 106).

However, Julius explores this wrong profiling of the northern African immigrant in Brussels more deeply beyond the "quick, suspicious glance at the tram". This gaze at the immigrant is informed by what Julius believes was a simmering, barely contained fear. He interprets this suspicion of the immigrant more meaningfully as a product of "The classic antiimmigrant view, which saw them as enemies competing for scarce resources, was converging with a renewed fear of Islam". (106) This constitutes a significant turning point for Julius. Although he gives hints on his feeling of unbelonging in New York from the outset of his narration through the solitary life that he lives, it is at this point that he expresses a clear opinion on migration and his status as a migrant. At this point, the cosmopolitan gives way to the migrant, awakening to his actual situation as a stranger in a city that might never understand the essence of his complex identity. This moment, his little confidence as a racial hybrid and postcolonial subject with a legitimate stake in western civilization dampened, given way to reasons for solidarity with fellow black migrants.

\section{Masked Selves in Teju Cole's Open City}

It's challenging to live in a country that has erased your past. She fell silent, and the sensation created by her words - I remember experiencing it as a subtle shift in the room's air pressure-deepened in the silence so that all we could hear was the going and coming outside my office door. She had closed her eyes for a moment as though she had fallen asleep. But then she continued, her shut eyelids now trembling: there are almost no Native Americans in New York City and very few in all Northeast. It isn't right that people are not terrified by this because this is a terrifying thing that happened to a vast population. And it's not in the past; it is still with us today; at least it's still with me (Cole, 27).

The symbol of the drunken Obatala creating deformed people on earth follows Cole even in Europe's metropolis. His carelessness is the protagonist's nightmare even abroad. It is this 
carelessness that sometimes Africans use to survive abroad "my brother was married to a German woman, but he divorced her when he got his residency papers, went back home, and brought over a Moroccan wife. Was that the plan all along? I don't know. The man is a hypocrite" (p. 125). One of the significant themes in Teju's Open City is masking true selves to survive in foreign lands. As a result, people carry different pasts with them as they move across nations:

It was as though the space had suddenly become heavy with all the stories these people were carrying... the quiet faces surely masked some pain I couldn't see...And I felt some of that mental constriction - invisible sometimes, but always there - that came whenever I was introduced to young men from Serbia or Croatia, Sierra Leone or Liberia. That doubt that said: these, too, could have killed and killed and only later learned how to look innocent (p. 139).

The idea of masking true identities by immigrants is made possible by transnationalism. When people move across nations, they repackage themselves, their stories and become new individuals with new stories:

I thought that she, too, might be here in Belgium as an act of forgetting. Her presence in the church might doubly be a means of escape: a refuge from the demands of family life and a hiding place from what she might have seen in the Cameroons or in the Congo, or maybe even in Rwanda. And perhaps her escape was not from anything she had done, but from what what she had seen (p. 140).

Despite the fact that it is presented as a work of fiction (a book), Open City's actual appeal is not centred on the plot or even on the characters as depicted by the narrator, whose voice has an autobiographical ring to it. However, rather than being what it appears to be, this could be an accomplishment of this writer's craft and imaginative skill, a disguised replication of the author's search for meaning and berthing in the rest of the globe, as well as a rich depository of phenomenally astute observations on a remarkable range of exciting topics. When it comes to daily awareness, Cole in Open City is a master teacher, consistently changing the everyday experience of the non-heroic narrative voice into an astonishing immersion in the city's lifeworld.

This is a narrative of what I would term deliberate relocation, somewhat reminiscent of Edward Said's half memoir, Out of Place. These smart and multitalented guys lived as exiles without losing their allegiance to their native nation. There are certainly some big changes, as well. Said grew enthusiastic about his Palestinian identity, a badge of distinction for him, and the center of his worries in the closing decades of his life. At the same time, Julius, the fictitious 'I' of Cole's narrator, is focused with his own sentiments, perceptions, and experience, observing public issues but avoiding participation by purposefully assuming a muted apolitical position. As a prominent profile Palestinian in America at this age, Said nearly insured that he would find himself besieged, which he did, particularly as a professor at Columbia University who spoke out in solidarity with the Palestinian cause. More broadly, being a Palestinian, or any type of Arab or Muslim, in New York City is clearly a different reality than being Nigerian or even an African. However, the difference may not be as large as it would initially appear. Julius is well informed that history has not been kind to individuals with his racial identity. He notices the many reminders around the city that Africans were not that long ago economically exchanged as slaves by New York financiers or exposed to colonial horrors, as in Belgium, which Julius stays for several weeks.

\section{CONCLUSION}

The paper has established that the notions of transnationalism, cosmopolitanism and xenophobia in postcolonial Africa have birthed new identities and that within the re-examination of these notions, the idea of Afropolitanism became central as a fulcrum upon which the present African identities can be fully understood. Undoubtedly, what has been considered African literature has witnessed additional literature that has escaped clear definition and blurred the boundaries of what can be called African Literature. The writers of this literature are young and creative, cosmopolitan African immigrants located either in Europe or North America. Some names include Chimamanda Adichie, NoViolet Bulawayo, Dinaw Mengestu,

21 This work is licensed under a Creative Commons Attribution 4.0 International License. 
Teju Cole, Taiye Selasi. The writings of these authors show an engagement with new thematic concerns, majorly defined by the kind of life that these authors have been exposed to. Yet, their experiences are similar to how the rest of Africans have gone throughout the centuries.

Moreover, the idea of unbelongingness in a cosmopolitan space, especially in the metropolis, has bedevilled many Africans who have moved from places they have been considered to belong. Using these texts as testimonies of these kinds of treatments and experiences, this article interrogated the ideas of home and away as portrayed in Teju Cole's Open city and as understood within an Afropolitan lens. The article also interrogated how Teju Cole used his characters, especially the protagonist, Julius, to re-read the notions of cosmopolitanism, transnationalism, and xenophobia in Open City. Essentially, the article interrogated how these terms are located in the globality of literature and how the African writer is using these terms as fodder upon which they commune with the world, presenting the African experience to the world, without necessarily trafficking Otherness.

\section{REFERENCES}

Bhabha, H. (1994). The location of culture. London: Routledge.

Cheah, P. (2006). Cosmopolitanism. Theory, culture \& society, 23(2-3), 486-496.

Chela, E. (2019, September 2). 'Not your traditional immigrant novel'-Efemia Chela reviews Beyond Babylon, the newly translated English debut by Somali-Italian author Igiaba Scego. The Johannesburg Review of Books. https://johannesburgreviewofbooks.com/2019/0 9/02/not-your-traditional-immigrant-novelefemia-chela-reviews-beyond-babylon-thenewly-translated-english-debut-by-somaliitalian-author-igiaba-scego/

Eze, C. (2014). Rethinking African culture and identity: the Afropolitan model. Journal of African Cultural Studies, 26(2), 234-247.

Cole, T. (2011). Open city: A novel. New York: Random House.
Mbembe, A. (2007). Afropolitanism. In Njami, S. (eds.), Africa Remix: Contemporary Art of a Continentm (26-30). Johannesburg: Jacana Media

Selasi, T. (2005, March 3). Bye-Bye Babar (or: What is an Afropolitan?)'. The LIP Magazine. https://thelip.robertsharp.co.uk/2005/03/03/byebye-barbar/

Ucham, E. (2014). African hybrids: Exploring Afropolitanism in 'Ghana Must Go'. NAWA, Journal of Language and Communication, 8(2), 63- 75. https://ir.nust.na/bitstream/10628/549/1/ Ucham.\%20African\%20hybrids.pdf 